\title{
Green Economy in the Post-pandemic Period: A Framework for Organizational Stakeholder Analysis
}

\author{
Helen Kavvadia \\ Institute of Political Science, University of Luxembourg \\ 11, Porte des Sciences, L-4366 Esch-sur-Alzette, Luxembourg \\ Tel: 352-466-644-9386Ｅ-mail: helen.kavvadia@ext.uni.lu
}

Received: January 10, 2022 Accepted: February 15, 2022 Published: February 21, 2022

doi:10.5296/ber.v12i1.19450ＵRL: https://doi.org/10.5296/ber.v12i1.19450

\begin{abstract}
In the current geo-economic landscape, the satisfaction of green economy goals and post-pandemic economic recovery dominate public discussion. Although climate change consequences are increasingly evidenced, economic actors devastated by the economic impact of the COVID-19 crisis are tempted to prioritize some "less green" activity, as demonstrated at the fall 2021 G20 summit and the United Nations COP26 summit in Rome and Glasgow, respectively. This tendency is reflected in the indecision of economic actors in setting future goals, partly as a result of diverging stakeholder forces applied to organizations. Although stakeholders' views are often not publicly known, they shape organizational policies. To understand the stance of organizations on the dilemma of "climate versus recovery," it is therefore important to decipher the stance of their stakeholders concerning the two alternative priorities. This article provides a framework for analyzing stakeholders' positions on this predicament based on how public or private their goals, consultations, and deliberations are. The validity of the proposed framework is tested in a case study approach through the examination of stakeholder preferences shaping the European Investment Bank's (EIB) decision-making. The European Union's (EU) bank has been chosen as a case study because it announced its "pivot" to become the first public international climate bank in 2019, and formed an important part of the Union's first response to the COVID-19 pandemic resilience and stimulus initiatives.
\end{abstract}

Keywords: Stakeholder governance, Corporate governance, Green economy, Post-pandemic Economic recovery

\section{Introduction}

The concept of organizational stakeholders has been developed over the last 40 years as a 
way to understand increasing organizational complexities and as a means to guide strategic decisions. The development of the concept opened new avenues in organizational thinking contrary to the Weberian bureaucratic theory of relatively stable organizations. The notion of stakeholders is akin to key concepts in industrial organization economics (von Neumann \& Morgenstern, 1944), but it has been triggered predominantly by research on the general systems theory, which views organizations as evolving and open systems in constant exchange with their environment (Von Bertalanffy, 1956). Ackoff and Emery followed suit and posited that social and organizational issues can be resolved through interaction with systems' stakeholders (Ackoff \& Emery, 1972). Systematic scholarly work on the stakeholder concept was kickstarted by Freeman and Reed in their seminal work in 1983. In this work, the pioneers of stakeholders' theory recall that the term stakeholder has been "coined in an internal memorandum at the Stanford Research Institute in 1963, [and refers to] 'those groups without whose support the organization would cease to exist'" (Freeman \& Reed, 1983, p. 89). Since then, the concept has gained momentum among scholars and practitioners as a result of its convergence with agency theory (Eisenhardt, 1989; Fama, 1980; Preston, 1998; Shankman, 1999; Wright, 2001) and the increasing importance assigned to transparency and accountability in organizational issues. In this vein, "Stakeholder theory' or 'stakeholder thinking' has emerged as a new approach to understand and remedy three interconnected business problems - the problem of understanding how value is created and traded, the problem of connecting ethics and capitalism, and the problem of helping managers think about management such that the first two problems are addressed" (Palmar et al., 2010, p. 4). By adopting "as a unit of analysis the relationships between a business and the groups and individuals who can affect or are affected by it then we have a better chance to deal effectively with these three problems" (Palmar et al., 2010, p. 408), stakeholder theory unravels covert aspects of organizational decision-making. In organizational studies, the concept has consequently been used as a basis for developing further aspects related to corporate strategy and governance, inasmuch as organizations are determined by the relationships among groups that have a stake in their activities (Jones, 1995; Walsh, 2005). In an effort to understand organizations, scholarly works that exemplify research and theorizing in this area examine how stakeholder relationships work and change over time, and search for ways to optimize the management of stakeholders by fashioning relationships among them in order to maximize organizational value and relevance (Freeman, 1984).

Despite criticism mainly due to abetting managerial opportunism (Blattberg, 2004; Jensen, 2000; Marcoux, 2000), stakeholder thinking has been used to analyze stakeholder conflicts of interest and how to manage them (Harrison et al., 2010). Being at the nexus of situational analysis and policy synthesis, stakeholder theory has evolved into one of the principal and widely accepted approaches serving research in areas characterized by a broad confluence of engendering and impacting factors. Due to the open and broad applicability of its approach, stakeholder thinking has been used in practice and theory beyond organizational studies. Different perspectives reflecting the concept in a wide broaching area of application have enabled its integration in sectors such as political science, economics, law, health care, public administration, ethics, and environmental policy (Freeman et al., 2010). Departing from environmental studies, stakeholder theory has been widely used in corporate social 
responsibility, sustainability, and climate studies (Darnall et al., 2010; Donaldson \& Preston, 1995; Driscoll \& Starik, 2004; Husted \& Allen, 2011; Lee, 2011; Orts \& Strudler, 2002; Phillips \& Reichart, 2000; Polonsky, 1995; Saleem et al., 2020; Topić, 2022). However, as already shown, the main body of research is either at a purely theoretical or at the antipodes at a purely empirical level, developing explanatory theories and testing theoretical perspectives, respectively (Freeman et al, 2010). On these grounds, the latter seminal work proposed a number of future research ideas, including the research question on "the key dimensions of each stakeholder relationship and how do we observe them" (Palmar et al., 2010, p. 446).

In addressing the aforementioned research gap, this article theorizes a framework of stakeholder analysis that can be applied in practice and tests it on a relevant case study. Aiming to understand how stakeholders' views shape the stance of organizations on the prevailing dilemma of climate versus recovery, the proposed framework follows an eclectic approach by drawing on stakeholder and agency theories. The framework is readily and easily applicable in practice for analyzing stakeholders' positions on this predicament based on how public or private their goals, consultations, deliberations, and outcomes are. The framework is applicable to private and public sector entities. It is particularly well suited to not-for-profit institutions and organizations with a political mandate, such as public banks, which are at the forefront of the application of industrial policies that can be confluent but often also divergent. This article claims that the more goals and deliberations are public, the more inclined organizations are to prioritize the green economy over pandemic recovery operations. The validity of the proposed framework is tested through an examination of stakeholder preferences shaping EIB decision-making (Kavvadia, 2021c). The EIB is an interesting case study for three reasons. First, for its relevance to the research question: Being the EU bank, the EIB is at the forefront of the dilemma, engaged to promote both climate and post-pandemic stimulus. Second, due to its operating impact, it is a major regional development bank (RDB), with lending and borrowing at the World Bank level, operating in 140 countries around the world. Third, for the replicability of the research results, given the EIB's incumbent status in the RDB field (Kavvadia, 2021a), which implies that its modus operandi is influential as a best practice setter and homeostatic organizational adaptation for a number of smaller banks at regional and national levels.

The rest of this paper is organized as follows. Section two reflects on the theoretical background of the framework, while Section three presents the application of the framework for understanding the way the EIB will face the challenge of combining climate finance with post-pandemic recovery and economic restart activity. The main results are summarized in the conclusion.

\section{Agency Theory versus Stakeholder Theory: Friends or Foes? A Synthesizing Framework for Stakeholder Analysis}

Both agency and stakeholder theories acknowledge the existence and importance of different groups of interest to organizations. They also suggest that differences among these groups have an impact on organizations' decision-making (Hill \& Jones, 1992). Nonetheless, 
stakeholder theory views organizations as being in constant interaction with a number of individual groups, which are within and beyond organizational boundaries, of vital importance to organizations. The results of the interests of these groups shape organizational identity and activity. With conflict among these groups representing an erosion of vital organizational functions, organizations aim to establish collective cooperation among groups. Scholars suggest that self-interest bids are preferable on an egalitarian basis, as organizations are to serve all groups equally (Gioia, 1999). In contrast, agency theory concerns "hierarchical relations," as it analyzes parties that are, both, "mandate providers" and, "mandate takers" (Cuevas-Rodríguez et al., 2012). In this context, parties often have diverging interests concerning key organizational issues. While acting on behalf of another party, the agent can nevertheless have different views than the principal and the "mandate provider." Consequently, the agent can deliberately choose to act in self-interest instead of promoting the interests of the principal. Such an eventual conflict between the two parties is often the source of a principal-agent problem. Agency problems, though, are not necessarily seen as threats to organizations, at least in the short term. Agency problems constitute dilemmas concerning the course of action to be followed, namely, the course suggested by the mandate provider or the course preferred by the mandate taker. Stakeholder theory has often been associated with finance issues, particularly financial returns (Cornell \& Shapiro, 1987; Jones, 1995; Zingales, 2000). Agency theory has often been associated with not-for-profit organizations that act as agents aiming to fulfill public mandates assigned to them by their principals (Carman, 2011; Van Puyvelde et al., 2011). To understand organizational situations, especially those concerning not-for-profit organizations, the need for a "synthetic" approach to the diverging objectives of interest groups and influencing their decision-making has been pointed out by several scholars (Abzug \& Webb, 1999; Hill \& Jones, 1992; Romano, 2013).

Public banks, such as the EIB, operate mostly as business entities in the real economy under market conditions, while having a not-for-profit character in order to achieve objectives of a politico-economic nature, such as the need to address market failures in the promotion of green economy or anti-cyclical activity, in order to achieve pandemic resilience and post-pandemic recovery. Given the EU's prioritization of climate-related growth through the European Green Deal (EGD) (EC, 2019a-2019c), and the EU's bold response to the COVID-19 crisis (European Commission (EC), 2020; EC, 2021 February), European public banks are at a crossroads, having to pursue two seemingly contradictory objectives of exclusively funding green investments, thereby limiting their range of operations, and expanding their activity in a broad range of projects for jobs and growth by supporting a whole range of schemes (Griffith-Jones \& Naqvi, 2020; Mertens et al., 2020; Romero, 2020). The diverging objectives of the EU and the national priorities of member states have already been pointed out (Kavvadia, 2021c).

Initially, in 2019, both the EU and EU member states pledged a political, economic, and socio-ecological transformational alignment with the Paris Agreement to "achieve climate neutrality by 2050 " (EC, 2019, p. 4). Subsequently, at the outbreak of the COVID-19 twin health and economic crisis in 2020, they put together the largest "stimulus initiative ever" (EC, 2021 April) in the form of the Next Generation EU (NGEU). With 2,018 trillion euros, 
the NGEU aims to address both problems of climate and post-COVID-19 restart for "building back better." Given the limited funds and unlimited needs, these two problems cannot be resolved easily, and especially not at the same time. A hierarchization in terms of objectives and a prioritization in terms of the time horizon to be addressed takes place among different groups and at different levels. The need for this hierarchization has been growing, as beyond the pandemic, Europe has been additionally hurt by an energy crisis and inflationary pressures that increase the cost of borrowing while decreasing disposable income for investments. Public banks have been adjusting to the ever-evolving policy prerequisites of their major stakeholders in the sense of the dynamic theory of public banks (Marois, 2021). However, as far as the dilemma under examination is concerned, the views of the EU and its member states are not aligned as already alluded (Fleming, 2021). Nonetheless, the stakeholders' circle of public banks is much broader, and includes a number of other interest groups at national, EU, and international levels, as will be demonstrated later in this article. Stakeholders of public banks fall into three main categories. The first is institutional stakeholders, who are of varying significance to banks. They include the EU member states that are the usual shareholders of public banks, the EC, as an executive EU policy-making and policy-coordinating institution, the European Parliament, national parliaments as legislative and democratic control institutions, and other smaller players, such as other EU and national institutions with less interaction and influence on the banks, as the European Court of Justice or the European Court of Auditors (ECA). The second is market stakeholders, including borrowers and investors in the lending and borrowing markets, as major stakeholders, and other partner banks, such as multilateral development banks (MDBs), RDBs, national development banks (NDBs), and commercial financing institutions. The third is civil society, including the general public and non-governmental organizations (NGOs).

To detect which alternative the public banks will follow, one has to identify the varying interests of their stakeholders in relation to the dilemma of a green economy versus a post-pandemic boost. However, beyond diverging interests, stakeholders have also differentiated approaches in their bargaining and deliberation methods, while additionally, their deliberation outcomes range from being completely transparent, as in the case of NGOs, to private and confidential under banking secrecy, as in the case of borrowers. This issue it has been addressed in scholarly works as part of stakeholder governance by distinguishing stakeholder interactions in two ways. First, through a longitudinal angle, by differentiating the bargaining process based on frequency of negotiations, on the basis of whether negotiations take place once, with reconciliation reached in a single negotiation (Krishna \& Serrano, 1996), or repeatedly over time, in a series of negotiations reconciled among stakeholders in a sequential manner (Machlup \& Taber, 1960). Second, it has been addressed through a participatory angle, which differentiates the bargaining process on the basis of the participating parties into bilateral (Machlup \& Taber, 1960) and forum-oriented negotiations (Hoskisson et al., 2018; Klein et al., 2012; Wang et al., 2009).

Viewing stakeholder governance management from the perspective of these two approaches as the outcome of bargaining among the actors who pursue diverging and possibly conflicting political, economic, and social interests, a generic framework of process-related patterns has 


\section{Macrothink Institute ${ }^{T M}$}

been developed. Nonetheless, the framework does not follow any of the above patterns of stakeholder interactions. Instead, it proposes a new angle, which differentiates stakeholder interaction based on the type of bargaining form followed, which tends to be: i) private, with individual or group consultations running in parallel or sequentially among actors in a confidential manner and with outcomes that are equally predominantly private; or ii) public, with negotiations within fora, where conflicts among stakeholders can be addressed collectively, and outcomes are in the public domain. The borrowers of public banks and NGOs exemplify these two categories of private versus public stakeholder interactions, respectively. In this sense, the interaction and bargaining forms applied at the stakeholder governance management level range on a continuum. On one end, there are more private and individual interactions, and on the other, there are more public and collective processes, whereby the outcomes tend to remain either private or become public. In other words, stakeholder governance ranges from a "privacy sphere" to a "transparency sphere," and stakeholder interaction can be located on a spectrum between each end as a measure of how private or how public the interaction with individual stakeholders is. This is figuratively depicted in Figure 1, elaborated upon by the author. Organizations involved in stakeholder management interact with different stakeholders who occupy different spots between the two extreme ends. The positioning of the various stakeholders seen aggregately creates an organizational stakeholder interaction "footprint" that is specific to each organization.

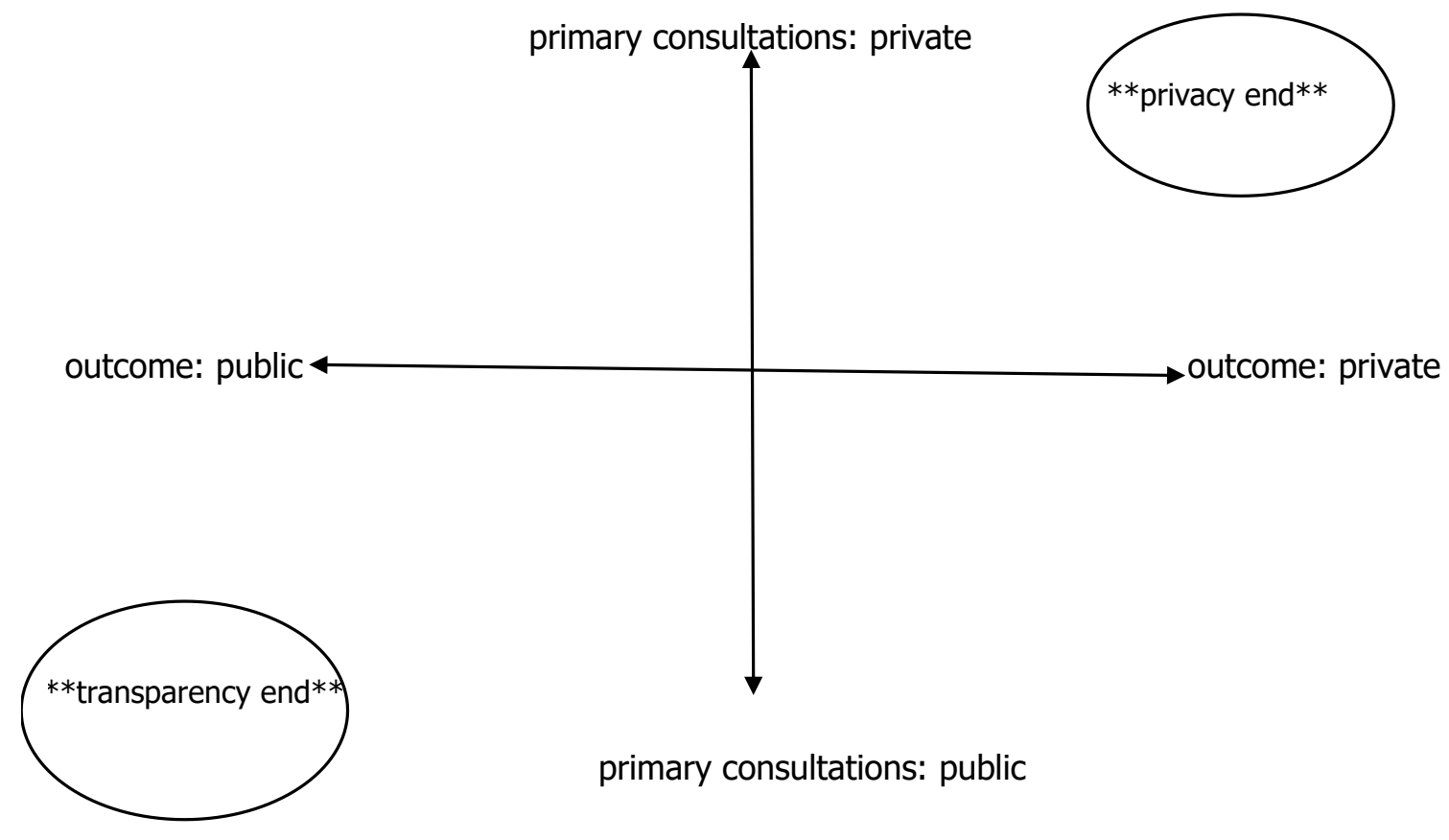

Figure 1. Stakeholder governance framework

\section{Applying the Stakeholder Governance Framework to the EIB}

Since its establishment, the EIB, as the EU's financial arm, has been adapting its remit and activity to match stakeholder demands (Clifton et al., 2014, 2018, 2021; Kavvadia, 2020) to 
preserve its relevance by meeting ever-evolving EU policy objectives and market requirements. The identification of the EIB major stakeholders shows that they fall into the generic categorization scheme mentioned above, which are illustratively shown in the EIB stakeholder governance framework in Figure 2. Unlike some stakeholder theory scholars claiming "egalitarianism" among all stakeholders (Gioia, 1999; Marcoux, 2000; Sternberg, 2000), there is prioritization in the case of the EIB (Kavvadia, 2021a-c), in line with agency theory. Among the EIB stakeholders, the EU member states, being the bank's shareholders and prime beneficiaries of its activity (90\% of its lending and $70 \%$ of its borrowing), are the bank's prime concern. Serving their interests and needs is the EIB's key remit parameter and a prerequisite for its continued relevance. In return, the bank's shareholders counter-offer continuous support through successive capital increases, placing the EIB at the top-of-the-list for shareholder support among RDBs (Kavvadia, 2021a-c). The member states' continuous EIB political and financial support can be viewed as recognition of the bank's contribution in meeting their priority objectives. The EIB prioritizes its stakeholders (McGahan, 2020) based on their importance for its vital interests and the bank's existence. Therefore, EIB stakeholder prioritization is primarily a function of the stakeholders' relative power over the bank (Kavvadia, 2021a, 2021b) and to a lesser extent based on legitimacy or urgency (Mitchell et al., 1997). The ECA, which, although legitimate, is not privileged, and NGOs, which, when often calling for the urgent EIB's activity adjustment, are not prioritized, are cases in point.

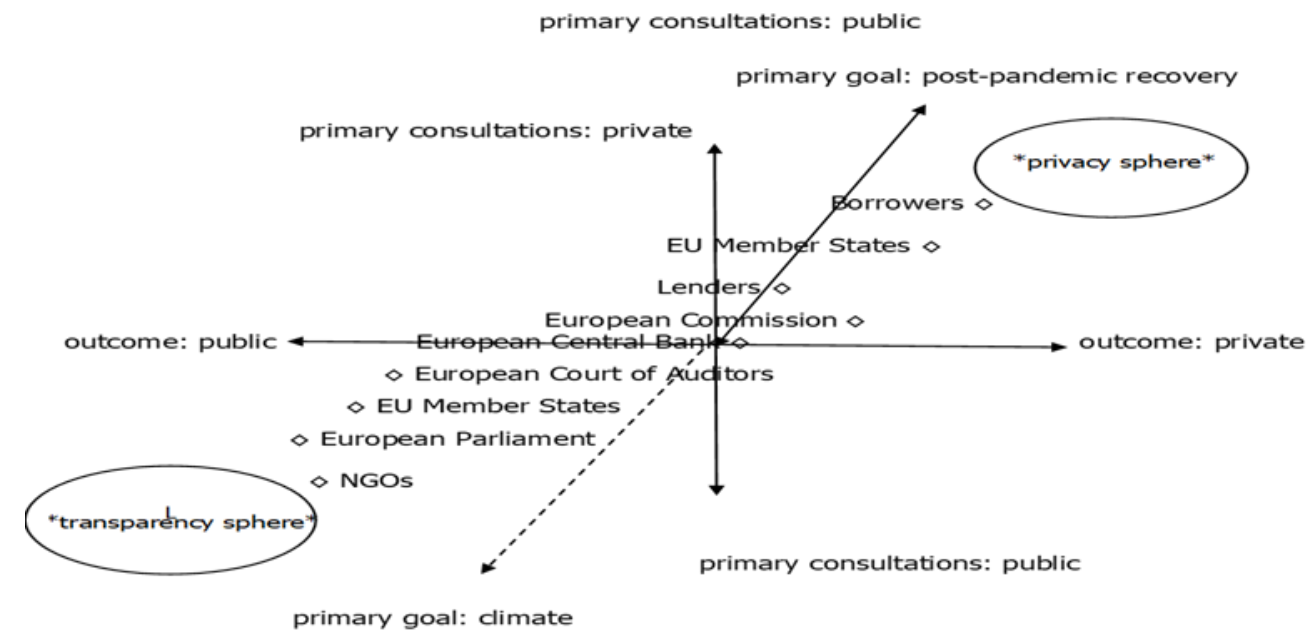

Figure 2. Stakeholder governance framework: EIB

In the current context, stakeholder stances related to the EIB double-axis activity for addressing both climate and pandemic crises are diverging, in the same fashion as not-for-profit organizations and, in particular, public banks. In the case of the EIB in particular, the stakeholder interests diverge for a broad variety of reasons, such as: i) sectoral and geographic asymmetries triggered by the pandemic (Bunte et al. 2021; Carney, 2020; Das et al., 2021; Eurostat, 2021); ii) funding preferences for concessional funding in the form of EU grants provided under the new Recovery and Resilience Facility as well as pre-existing 
programs, instead of EIB loans which have to be repaid and come with strict conditions; iii) macroeconomic context, as countries with fiscal surpluses are benefiting from the timing of the NGEU funds-outflow, given that payouts will be effective in 2023, while countries with short-term requirements, mostly those that hit by the global financial crisis, can only bridge their funding needs with loans from the EU, which have to be repaid in 2028-2058, and additional EIB loans; iv) capital market conditions, as the EC becomes an important EIB competitor (Ainger \& Nardelli, 2021) through its new 30-year Eurobonds which are to be issued for a planned EUR 1 trillion over the next five years in order to fund the EU loans mentioned above to the countries with no fiscal surpluses; v) paucity of funds, as the European financial response package falls short of the economic recovery needs (Picek, 2020), provoking a rally among countries and project promoters for securing financing for urgent short-term survival needs rather than long-term funding for climate-related transformations; vi) fund-distribution mechanisms, favoring predominantly the EIB's existing network of partner financial institutions which intermediate the channeling of EIB funds to small and medium-sized enterprises (SMEs) (Clifton et al., 2020), continuing the path of favoring opaqueness (Clifton et al., 2020; Griffith-Jones \& Naqvi, 2020), while increasing competition among EIB's peers addresses the "need to level the playing field" (Mertens et al., 2020 , p. 8) and the need to develop novel approaches for tackling the twin crises (Carney, 2020); vii) financialization of COVID-19 related investments through intermediation via the banking sector, which has been criticized as inappropriate for public goods sectors such as health (Clifton et al., 2020; Counter Balance (CB), 2021).

In the present situation, member states' stances diverge widely. Even countries that pioneered the idea of the EIB's "pivot" to climate, such as France (Krukowska, 2019), are currently strained and in need of growth and jobs. As a result of private deliberations, and without risking losing face, some counties may either actively seek or tolerate pseudo- green but broader growth-generating EIB activity (Fleming, 2021). In contrast, the EC is committed to the EGD, which constitutes the leitmotiv of the EC President von der Leyen term. While the Commission is evolving to be an increasingly important stakeholder of the EIB through their interlinked activities, by blending budgetary resources with EIB loans, in parallel, the Commission is also developing to be an EIB competitor, as demonstrated by its planned vast capital markets issuance program over the next few years. The Commission's "cultural gap" (EP, 2016, p. 103) and "discontent" (Mertens \& Thiemann, 2022, p. 21) have led the Commission to frequently stress the need for strengthening its oversight over the EIB to ensure increased transparency. Yet, under the sway of the diverging stances of EU member states (Pop, 2022), the Commission itself deviated from its strict green initial objectives by labeling gas and nuclear energy production as climate-friendly in its 2022 proposal of the EU Taxonomy - an official list of investments considered "environmentally sustainable" (EC, 2022). The composition of the European Parliament (EP) is currently "greener" than ever, as reflected in its official deliberations. Yet, its members are sensitive to calls from their constituencies for jobs and growth aided by broad-reaching EIB activity for post-pandemic growth. This "diphonic" stance of the members of the EP is manifested in voicing diverging views when deliberations are public or private. Despite some of them being able to claim a leading climate role (Kavvadia, 2021a), the EIB's peers, including MDBs, RDBs, and NDBs, 
have been caught by surprise when the EIB "pivoted" to climate in 2019. Nonetheless, EIB peers follow suit on climate lending thresholds for political and economic self-interests to maintain their relevance and market penetration. Yet, the EIB's peers enjoy more flexibility than the EIB itself in shaping their policies and lending portfolios as they do not belong to a supranational economic governance structure such as the EU. In some cases, they can even benefit by enlarging their portfolios through projects that cannot be funded by the EIB on the basis of the strict climate-related-criteria (Brunsden \& Khan, 2018). Investors in capital markets have supported climate-related initiatives since the EIB pioneered the first ever green bond in 2007. Nonetheless, green bonds account for only $6.5 \%$ of the EIB's yearly issuance program, on average, which was well below the EIB's climate-related lending average of $25 \%$ of the bank's aggregate yearly activity volume until 2018, and was subsequently increased to $40 \%$, demonstrating an appetite for climate-related investments. However, the current COVID-19-related economic crisis has halted a number of climate-related projects, as several green investment plans have been postponed in order to prioritize business continuity needs, some of which are definitely not really green and in some cases brown (CB, 2020a, 2020b).

As shown in the example of the Commission's change of attitude concerning gas and nuclear energy, the ambivalence of stakeholders' stances gives leeway to, if not encourages, the EIB to apply a lax lending policy, despite its commitment to become fully Paris Agreement aligned in 2022. In its effort to satisfy mainly the EU member states, as its prime stakeholders, the EIB risks being drawn into an ambivalent activity, for either "building back better" following the EU climate-related policy or simply "building back" for rebounding economic activity after the pandemic. The likelihood of such a future course of action for the EIB increased further with the energy crisis in 2021. Although, in an unusual act, the EIB criticized the EC's "jumbled" additions of nuclear- and gas-energy production to the EU taxonomy that categorizes investments considered as acceptable for climate-related funding (Pop, 2022), fears are mounting that the EIB will also shift toward unclear practices, whereby non-green projects could be included in its climate-friendly finance activity, through possible creative statistics. Under the pressure of contradictory stances of its major stakeholders concerning the dilemma of climate versus post-COVID-19 rebound that is illustrated in Figure 3, the EIB might practice what in RDB parlance is coined as "window-dressing" of results (Clifton et al., 2020) by categorizing project that are not green as green projects in order to keep promise of being the EU's climate bank and satisfy broad growth objectives of its main stakeholders - the EU member states. The practice can be easily performed through the EIB's lending facilities to SMEs (Clifton et al., 2021), channeled through partner banks, without the necessary transparency, given that such details are considered by the EIB to be sensitive commercial data from the intermediating banks, which are the EIB's borrowers. 


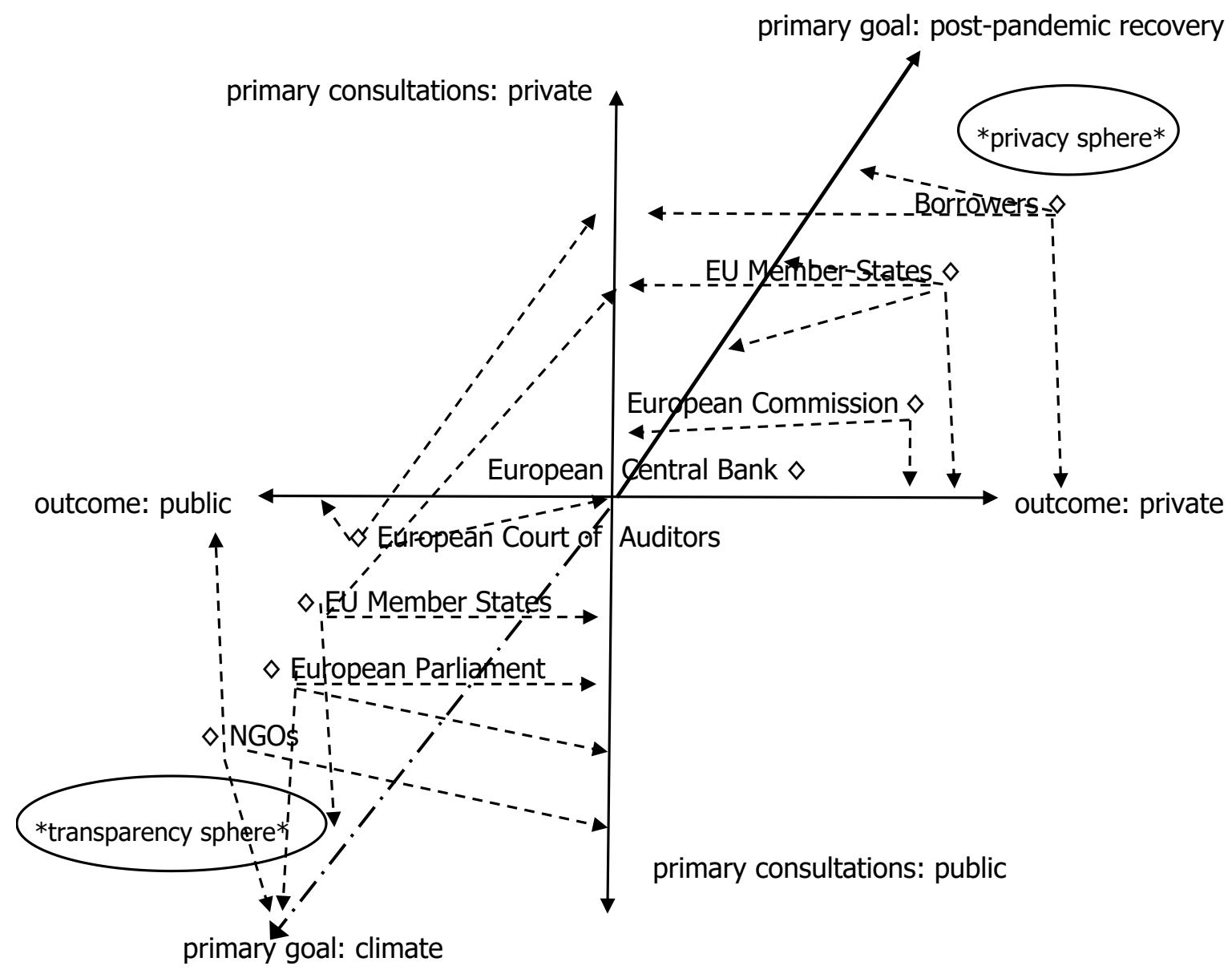

Figure 3. Stakeholder governance framework: EIB restrictive versus expansive dilemma

\section{Conclusion}

Although climate change consequences are increasingly evidenced around the world, economic actors do not seem to be pursuing fully green economy objectives. Devastated by the economic impact of COVID-19, the energy crisis in 2021, and the inflationary pressures in 2022, countries are tempted to prioritize some pseudo-green but growth-generating activity, as demonstrated in the G20 and United Nations COP26 summits. To understand the interwoven network of economic actors in their roles as stakeholders of key organizations that are called to address these two seemingly contradictory objectives, this paper developed an eclectic framework of stakeholder governance, drawing on agency and stakeholder theories. The framework is based on a novel approach that differentiates stakeholder interaction based on the type of bargaining form followed for deliberations that tend to be either private or public. To test the framework, the paper used the EIB, the EU's financing arm, as a case study. The EIB, like all public banks, is at the forefront of policies that support these two bold but opposing political and economic goals of climate versus post-COVID-19 rebound. As not-for-profit organizations, public banks support policy objectives but operate in the real economy, consequently facing highly divergent stakeholder expectations. As a 
result, public banks remain hesitant and open to creative statistics in an effort to satisfy their stakeholder demands as well as their own self-interests. This practice, which has been coined in the banks' jargon as "window-dressing," is triggered by the dichotomy of how private or how public the goals, deliberations, consultations, and outcomes of their stakeholders are. Stakeholders often express contradictory requirements in private rather than in public. The proposed framework assists in unveiling the role of stakeholders when hidden in the background and provides an illustrative overview of the positioning of each one of them concerning the dilemma of climate versus recovery. The EIB case study, which can be replicated with other public banks, demonstrated that while the EU calls for a unifying approach, blending climate and pandemic responses, economic actors appear divided and influence, with their stances, the activity of public banks. At a national level, the EU member states have diverging priorities related to the dilemma of climate-countercyclical action depending mainly on their economic situation, economic model, and energy mix. Other economic actors who play a role in the stakeholder governance of public banks also demonstrate ambivalence, depending on the urgency of their funding needs, as well as their preferences, which can be voiced differently publicly and behind closed doors.

\section{Acknowledgments}

This research did not receive a specific grant from funding agencies in the public, commercial, or not-for-profit sectors. The ideas presented in this paper were presented in rough form at the 2021 SASE Conference, held remotely from July 2-5, 2021, at panel TH04-Development Finance in a Changing Global Context on July 5, 2021. The author thanks the panel discussants Daniel Mertens and Matthias Thiemann, as well as the BER reviewers, for their valuable comments.

\section{References}

Abzug, R., \& Webb, N. J. (1999). Relationships between nonprofit and for-profit organizations: A stakeholder perspective. Nonprofit and Voluntary Sector Quarterly, 28(4), 416-431. https://doi.org/10.1177/0899764099284003

Ackoff, R. L., \& Emery, F. E. (1972). On purposeful systems. Aldine-Atherton Press.

Ainger, J., \& Nardelli, A. (2021). EU lays out \$1 trillion debt plan to challenge treasuries. Bloomberg. [Online] Available:

https://www.bloomberg.com/news/articles/2021-04-13/eu-to-lay-out-1-trillion-debt-plan-to-st art-rivaling-treasuries

Blattberg, C. (2004). Welfare: Towards the patriotic corporation. From pluralist to patriotic politics: Putting practice first. Oxford University Press.

Bunte, T., Eisentraut, S., Hartmann, L., Carr, R., Hammelehle, J., Kabus, J., Miehe, L., Pfeiffer, S., Stärk, F., \& Mudie-Mantz, A. (2021, June). Between states of matter. Competition and cooperation. Munich Security Report. https://doi.org/10.47342/CYPE1056

Carman, J. G. (2011). Understanding evaluation in nonprofit organizations. Public Performance \& Management Review, 34(3), 350-377. 
https://doi.org/10.2753/PMR1530-9576340302

Carney, M. (2020). Putting values above valuations. Economist, 54. [Online] Available: https://www.economist.com/by-invitation/2020/04/16/mark-carney-on-how-the-economy-mu st-yield-to-human-values

Clifton, J., Diaz-Fuentes, D., \& Revuelta, J. (2014). Financing utilities: How the role of the European Investment Bank shifted from regional development to making markets. Utilities Policy, 29(1), 63-71. https://doi.org/10.1016/j.jup.2013.10.004

Clifton, J., Diaz-Fuentes, D., \& Gómez, A. L. (2018). The European investment bank: Development, integration, investment? Journal of Common Market Studies, 56(4), 733-750. https://doi.org/10.1111/jcms.12614

Clifton, J., Diaz-Fuentes, D., \& Howarth, D. (2021). Regional development banks in the world economy. In J. Clifton, D. Díaz Fuentes \& D. Howarth (Eds.), Regional development banks in the world economy (pp. 1-30). Oxford University Press.

https://doi.org/10.1093/oso/9780198861089.003.0001

Cornell, B., \& Shapiro, A. C. (1987). Corporate stakeholders and corporate finance. Financial Management, 16(1), 5-14. https://doi.org/10.2307/3665543

Counter Balance. (2020, June). The EU climate bank—Greenwashing or a banking revolution? [Online] Available: https://counter-balance.org/media/episode-8-eu-climate-bank

Counter Balance. (2020, July). Too soon to call the EIB the 'EU Climate Bank.' [Online] Available: https://counter-balance.org/publications/too-soon-to-call-the-eib-the-eu-climate-bank

Counter Balance. (2021). The European green deal: Reclaiming public investments for a real socio-ecological transformation. [Online] Available: https://counter-balance.org/publications.

Counter Balance. (2022). The European Guarantee Fund: The unknown tool of the economic recovery package. [Online] Available:

https://counter-balance.org/publications/eibs-main-pandemic-response-mired-in-secrecy

Cuevas-Rodríguez, G., Gomez-Mejia, L. R., \& Wiseman, R. M. (2012). Has agency theory run its course? Making the theory more flexible to inform the management of reward systems. Corporate Governance: An International Review, 20(6), 526-546.

https://doi.org/10.1111/corg.12004

Cuypers, I. R., Koh, P. S., \& Wang, H. (2016). Sincerity in corporate philanthropy, stakeholder perceptions and firm value. Organization Science, 27(1), 173-188.

https://doi.org/10.1287/orse.2015.1030

Darnall, N., Henriques, I., \& Sadorsky, P. (2010). Adopting proactive environmental strategy: The influence of stakeholders and firm size. Journal of Management Studies, 47(1), 1072-1094. https://doi.org/10.1111/j.1467-6486.2009.00873.x

Das, S., Lian, W., Magistretti, G., Pugacheva, E., \& Wingender, P. (2021). After-effects of the COVID-19 pandemic: Prospects for medium-term economic damage. In International 
Monetary Fund. Research Dept. (Eds.), World economic outlook, April 2021: Managing divergent recoveries (pp. 43-61). International Monetary Fund.

https://doi.org/10.5089/9781513575025.081

De la Porte, C., \& Jensen, M. D. (2021). The next generation EU: An analysis of the dimensions of conflict behind the deal. Social Policy \& Administration, 55(2), 388-402. https://doi.org/10.1111/spol.12709

Donaldson, T., \& Preston, L. E. (1995). The stakeholder theory of the corporation: Concepts, evidence, and implications. Academy of Management Review, 20(1), 65-91.

https://doi.org/10.2307/258887

Driscoll, C., \& Starik, M. (2004). The primordial stakeholder: Advancing the conceptual consideration of stakeholder status for the natural environment. Journal of Business Ethics, 49(1), 55-73. https://doi.org/10.1023/B:BUSI.0000013852.62017.0e

Eisenhardt, K. M. (1989). Agency theory: An assessment and review. Academy of Management Review, 14(1), 57-74. https://doi.org/10.2307/258191

European Commission. (2019, June). Taxonomy technical report. Financing a sustainable European economy. Technical Expert Group. [Online] Available:

https://ec.europa.eu/info/sites/default/files/business_economy_euro/banking_and_finance/doc uments/190618-sustainable-finance-teg-report-taxonomy_en.pdf

European Commission. (2019, November 27). Speech by President-elect von der Leyen in the European Parliament Plenary on the occasion of the presentation of her College of Commissioners and their programme. [Online] Available:

https://ec.europa.eu/commission/presscorner/detail/en/speech_19_6408

European Commission. (2019, December 11). Communication from the Commission to the European Parliament, the European Council, the Council, the European Economic and Social Committee and the Committee of the Regions. [Online] Available:

https://ec.europa.eu/info/sites/default/files/european-green-deal-communication_en.pdf

European Commission. (2020, November 11). EU'S next long-term budget and NextGenerationEU: Key facts and figures. [Online] Available:

https://ec.europa.eu/info/sites/default/files/about_the_european_commission/eu_budget/mff_f actsheet_agreement_en_web_20.11.pdf

European Commission. (2021, February 10). The recovery and resilience facility. [Online] Available: https://ec.europa.eu/info/sites/default/files/economy-finance/rrf-factsheet.pdf.

European Commission. (2021, April 29). The EU's 2021-2027 long-term budget \& NextGenerationEU. [Online] Available:

https://op.europa.eu/en/publication-detail/-/publication/d3e77637-a963-11eb-9585-01aa75ed 71a1/language-en

European Commission. (2022, February 2). Questions and answers on the EU Taxonomy Complementary Climate Delegated Act covering certain nuclear and gas activities. [Online] 
Available: https://ec.europa.eu/commission/presscorner/detail/en/QANDA_22_712.

European Parliament. (2016). Research for REGI Committee-Review of the role of the EIB group in European cohesion policy. [Online] Available:

https://www.europarl.europa.eu/RegData/etudes/STUD/2016/563410/IPOL_STU(2016)5634 10_EN.pdf

Eurostat. (2021, June 8). Euroindicators. [Online] Available:

https://ec.europa.eu/eurostat/documents/2995521/11563119/2-08062021-AP-EN.pdf/eead4cc 5-f4f2-a087-9ded-a1b15bf2394a?t=1623140343558

Fama, E. F. (1980). Agency problems and the theory of the firm. Journal of Political Economy, 88(2), 375-90. https://doi.org/10.1086/260866

Fleming, S. (2021, April 29). These countries are leading the way on a post-pandemic green recovery. World Economic Forum. [Online] Available:

https://www.weforum.org/agenda/2021/04/countries-leading-post-pandemic-green-recovery/

Freeman, R. E., \& Reed, D. L. (1983). Stockholders and stakeholders: A new perspective on corporate governance. California Management Review, 25(3), 88-106.

https://doi.org/10.2307/41165018

Freeman, R. E., Harrison, J. S., Wicks, A. C., Parmar, B. L., \& De Colle, S. (2010). Stakeholder theory: The state of the art. Cambridge University Press.

https://doi.org/10.1017/CBO9780511815768

Gioia, D. A. (1999). Practicability, paradigms, and problems in stakeholder theorizing. Academy of Management Review, 24(2), 228-232. https://doi.org/10.2307/259077

Griffith-Jones, S., \& Naqvi, N. (2020, July). Industrial policy and risk sharing in public development banks: Lessons for the post-COVID response from the EIB and EFSI. Global Economic Governance Program. [Online] Available:

https://www.geg.ox.ac.uk/sites/geg.bsg.ox.ac.uk/files/2020-07/GEG\%20WP\%20143\%20July $\% 202020 \% 20$ Industrial\%20policy\%20and\%20risk\%20sharing\%20in\%20public\%20develop ment\%20banks.pdf

Harrison, J. S., Bosse, D. A., \& Phillips, R. A. (2010). Managing for stakeholders, stakeholder utility functions, and competitive advantage. Strategic Management Journal, 31(1), 58-74. https://doi.org/10.1002/smj.801

Hill, C. W. L., \& Jones, T. M. (1992). Stakeholder-agency theory. Journal of Management Studies, 29(2), 131-154. https://doi.org/10.1111/j.1467-6486.1992.tb00657.x

Hörisch, J., Freeman, R. E., \& Schaltegger, S. (2014). Applying stakeholder theory in sustainability management: Links, similarities, dissimilarities, and a conceptual framework. Organization \& Environment. https://doi.org/ 10.1177/1086026614535786

Hoskisson, R. E., Gambeta, E., Green, C. D., \& Li, T. X. (2018). Is my firm-specific investment protected? Overcoming the stakeholder investment dilemma in the resource-based 
view. Academy of Management Review, 43(1), 284-306.

https://doi.org/10.5465/amr.2015.0411

Husted, B. W., \& Allen, D. B. (2011). Corporate social strategy: Stakeholders engagement and competitive advantage. Cambridge University Press.

https://doi.org/10.1017/CBO9780511667060

Jones, T. M. (1995). Instrumental stakeholder theory: A synthesis of ethics and economics. Academy of Management Review, 20(1), 404-437. https://doi.org/10.2307/258852

Kavvadia, H. (2020). From a policy bank to a crowding-in bank: The development of the European Investment Bank in the last ten years, as seen through its business model. Croatian Regional Development Journal, 1(1), 30-43. https://doi.org/10.2478/crdj-2021-0003

Kavvadia, H. (2021a). The European Investment Bank and the Asian Infrastructure Investment Bank: Incumbents and challengers in the field of regional development banking. In J. Clifton, D. Díaz Fuentes \& D. Howarth (Eds.), Regional development banks in the world economy. Oxford University Press. https://doi.org/10.1093/oso/9780198861089.003.0012

Kavvadia, H. (2021b). The European Investment Bank's quantum leap to become the world's first international climate bank. Politics and Governance, 9(2), 185-195.

https://doi.org/10.17645/pag.v9i2.3921

Kavvadia, H. (2021c). Restrictive or expansive? European Investment Bank's challenge to equipoise climate finance with post-pandemic boost. Fulbright Review of Economics and Policy, 1(2), 170-185. https://doi.org/10.1108/FREP-10-2021-0059

Klein, P. G., Mahoney, J. T., McGahan, A. M., \& Pitelis, C. N. (2012). Who is in charge? A property rights perspective on stakeholder governance. Strategic Organization, 10(2), 304-315. https://doi.org/10.1177/1476127012453108

Krishna, V., \& Serrano, R. (1996). Multilateral bargaining. Review of Economic Studies, 63(1), 61-80. https://doi.org/10.2307/2298115

Krukowska, E. (2019, July 12). Macron's dream of a climate bank gets boost from new EU leader. Bloomberg. [Online] Available:

https://www.bloomberg.com/news/articles/2019-07-12/macron-s-dream-of-a-climate-bank-ge ts-boost-from-new-eu-leader

Lee, M-D. P. (2011). Configuration of external influences: The combined effects of institutions and stakeholders on corporate social responsibility strategies. Journal of Business Ethics, 102(1), 281-298. https://doi.org/10.1007/s10551-022-05047-8

Machlup, F., \& Taber, M. (1960). Bilateral monopoly, successive monopoly, and vertical integration. Economica, 27(1), 101-119. https://doi.org/10.2307/2550895

Marcoux, A. M. (2000). Balancing act. In J. R. Desjardins \& J. J. McCall (Eds.), Contemporary issues in business ethics (4th ed.) (pp. 92-100). Wadsworth.

Marois, T. (2021). A dynamic theory of public banks (and why it matters). Review of Political 
Economy, 1-16. https://doi.org/10.1080/09538259.2021.1898110

McGahan, A. M. (2020). Where does an organization's responsibility end? Identifying the boundaries on stakeholder claims. Academy of Management Discoveries, 6(1), 8-11. https://doi.org/10.5465/amd.2018.0218

Mertens, D., \& Thiemann, M. (2022). The politicization of the EIB? Managing hybridity and resource dependence in European economic governance. The politicization of the EIB? In L. Coppolaro \& H. Kavvadia (Eds.), Deciphering the EIB: History, politics, and economics. Routledge.

Mertens, D., Rubio, E., \& Thiemann, M. (2020). COVID-19 and the mobilisation of public development banks in the EU. HAL Open Science, hal-02586063. [Online] Available:

https://hal.archives-ouvertes.fr/hal-02586063/_

Mitchell, R. K., Agle, B. R., \& Wood, D. J. (1997). Toward a theory of stakeholder identification and salience: Defining the principle of who and what really counts. Academy of Management Review, 22(1), 853-886. https://doi.org/10.2307/259247

Orts, E. W., \& Strudler, A. (2002). The ethical and environmental limits of stakeholder theory. Business Ethics Quarterly, 12(2), 215-233. https://doi.org/10.2307/3857811

Palmar, B. L., Freeman, R. D., Harrison, J. S., Wicks, A. C., de Colle, S., \& Purnell, L. (2010). Stakeholder theory: The state of the art. The Academy of Management Annals, 3(1), 403-445. https://doi.org/10.1080/19416520.2010.495581

Perez-Batres, L. A., Doh, J. P., Miller, V., \& Pisani, M. J. (2012). Stakeholder pressures as determinants of CSR strategic choice: Why do firms choose symbolic versus substantive self-regulatory codes of conduct? Journal of Business Ethics, 110(1), 157-172.

https://doi.org/10.1007/s10551-012-1419-y

Phillips, R. A., \& Reichart, J. (2000). The environment as a stakeholder? A fairness-based approach. Journal of Business Ethics, 23(2), 185-197.

https://doi.org/10.1023/A:1006041929249

Picek, O. (2020). Spillover effects from next generation EU. Intereconomics, 55(5), 325-331. https://doi.org/10.1007/s10272-020-0923-z

Polonsky, M. J. (1995). A stakeholder theory approach to designing environmental marketing strategy. Journal of Business \& Industrial Marketing, 10(3), 29-46.

https://doi.org/10.1108/08858629510096201

Pop, V. (2022, January 28). European Investment Bank criticizes Brussels' sustainable finance rules. Financial Times. [Online] Available: https://on.ft.com/351XH5E

Preston, L. E. (1998). Agents, stewards, and stakeholders. Academy of Management. The Academy of Management Review, 23(1), 9-13. https://doi.org/10.5465/amr.1997.9707180258

Romano, M. (2013). Common agency theory, corporate governance, and not-for-profit organizations. In L. Gnan, A. Hinna, \& F. Monteduro (Eds.), Conceptualizing, and 
researching governance in public and non-profit organizations (Studies in Public and Non-Profit Governance, Vol. 1 (pp. 91-113). Emerald Group Publishing. https://doi.org/10.1108/S2051-6630(2013)0000001008

Romero, M. J. (2020). Reclaiming public banks to finance sustainable and equitable recovery post COVID-19. In D. A. McDonald, T. Marois \& D. V. Barrowclough (Eds.), Public Banks and Covid-19: Combatting the Pandemic with Public Finance. Municipal Services Project and UNCTAD.

Saleem, F., Zhang-Zhang, Y., Imran Malik, M., \& Allui, A. (2020). Revisiting stakeholder theory and environmentalism: Evidence from an emerging economy. Sustainability 2020, 12(20), 8751. https://doi.org/10.3390/su12208751

Shankman, N. A. (1999). Reframing the debate between agency and stakeholder theories of the firm. Journal of Business Ethics, 19(4), 319-334.

https://doi.org/10.1023/A:1005880031427

Sternberg, E. (2000). Just business: Business ethics in action (2nd ed.). Oxford University Press.

Topić, M. (2022). Corporate social responsibility and environmental affairs in the British Press. Routledge. https://doi.org/10.4324/9781003091592

Walsh, J. P. (2005). Taking stock of stakeholder management. Academy of Management Review, 30(2), 426-438. https://doi.org/10.2307/20159128

Wang, H. C., He, J., \& Mahoney, J. T. (2009). Firm-specific knowledge resources and competitive advantage: The roles of economic- and relationship-based employee governance mechanisms. Strategic Management Journal, 30(2), 1265-1285.

https://doi.org/10.1002/smj.787

Wright, P., Mukherji, A., \& Kroll, M. J. (2001). A reexamination of agency theory assumptions: Extensions and extrapolations. The Journal of Socio-Economics, 30(5), 413-429. http://dx.doi.org/10.1016/S1053-5357(01)00102-0

Van Puyvelde, S., Caers, R., Du Bois, C., \& Jegers, M. (2011). The governance of nonprofit organizations. Nonprofit and Voluntary Sector Quarterly, 41(3), 431-451.

http://dx.doi.org/10.1177/0899764011409757

Von Bertalanffy, L. (1956). General systems theory. In Society for the Advancement of General Systems Theory. General Systems. Yearbook. Vol. I. British Journal for the Philosophy of Science, 9(34), 170-171. https://doi.org/10.1093/bjps/IX.34.170

Von Neumann, J., \& Morgenstern, O. (1944). Theory of games and economic behavior. Princeton University Press.

Zingales, L. (2000). In search of new foundations. Journal of Finance, 55(4), 1623-1653. https://doi.org/10.1111/0022-1082.00262 


\section{Copyright Disclaimer}

Copyright for this article is retained by the author(s), with first publication rights granted to the journal.

This is an open-access article distributed under the terms and conditions of the Creative Commons Attribution license (http://creativecommons.org/licenses/by/4.0/). 